(8) End tidal $\mathrm{CO}_{2}$ values were estimated for 5 minutes but only one value was quoted. What happened to the end tidal $\mathrm{CO}_{2}$ over this 5 minutes?

We feel that there is insufficient evidence at present in the general metabolic and psychiatric literature for the authors to make the statement that 'some chemical differences between most depressed patients and controls are easily explained', and their conclusion that response to drug treatment may be due to effects on the blood brain barrier of $\mathrm{CO}_{2}$ levels is premature in the extreme. It would be sad if work which could be extremely valuable in evaluating specific relationships between control mechanisms at, or below, limbic system level and cortical function were obscured by hasty conclusions from enthusiastic workers.

\section{P. Mrtchell-Heggs}

A. Guz

K. MURPHY

\section{References}

Garattini, S., Mussin, E. \& Randell, L. (1973) The Benzodiazepines. New York: Raven Press.

GregG, I. (1974) Hospital Update. December.

Guz, A. et al (1977) Clin. Sci. \& Mol. Med., 52, 2-14.

MorA, J. D. et al (1976) Brit. J. Psychiat., 129, 457-64.

Charing Cross Hospital,

Fulham Palace Road,

London W6 $8 R F$
Dickens dramatized a story told to him of a Miss Donnithorne. This lady was the daughter of Judge James Donnithorne of Sydney. In her case too, the bridgegroom did not appear, and thereafter all the wedding decorations, etc, were kept as they had been arranged. Except for the doctor and the solicitor, the house was locked against all visitors; it was said to be haunted and was avoided by the children of the suburb. Miss Donnithorne died in 1886 at an advanced but unknown age, while Dickens wrote his novel in 1860 . The dates would allow the real event to have taken place before the writing of the novel, though I believe that Dickensians hotly dispute this.

Though eponyms are now frowned upon in medical terminology, the term 'Miss Havisham syndrome' may be an appropriate one in describing a situation where an individual has not faced or 'worked through' a loss (whether death of a loved one or disappointment of any kind) but has attempted to maintain an inappropriate status quo.

\section{Roxanas}

Health Commission of New South Wales, Gladesville Hospital, Victoria Road, Gladesville, NSW 2 III, Australia

\section{References}

1. CRrtchley, M. (1970) The Miss Havisham syndrome. History of Medicine, 1, 2-5.

2. Tyrrell, J. R. (1952) Old Books, Old Friends, Old Sydney, pp 22-3. Sydney: Angus \& Robertson.

\section{MOURNING}

DeAr SiR,

Gardner and Pritchard's article ('Mourning, Mummification and Living with the Dead' (Joumal, January 1976, 130, pp 23-8) describes some extreme examples of unresolved grief reactions. Their use of the term 'mummification' is certainly appropriate.

In their article they cite milder examples of abnormal reactions to bereavement, e.g. Queen Victoria's case, and these are in fact more commonly observed in practice. They do not mention an alternative term, which to my knowledge was first used by Macdonald Critchley the 'Miss Havisham syndrome' ( 1 ). The name is, of course, taken from Charles Dickens' Great Expectations. Miss Havisham in the novel was jilted by her fiancé on their wedding day and from that time became a recluse, wearing the fading satin of her bridal dress and 'freezing' the house as it was on that day.

Critchley says that Miss Havisham was a fictional character. Yet it has been suggested (Tyrrell (2)), that

\section{SPEECH IN DEPRESSIVE STATES}

Dear Str,

We are grateful to Christopher Ounsted (Journal, March 1977, 130, p 315) for drawing our attention to a case report which describes the changes in spontaneous speech in a manic-depressive patient. We have to comment, however, on his surprising statement that the detailed analysis of tape-recorded counting in depressed patients undertaken by us (Szabadi, Bradshaw and Besson, 1976) "is not required'.

I. Counting os spontaneous speech. The use of a sample of 'automatic speech' (Hughlings Jackson, 1878), such as counting, has advantages compared to the recording of 'spontaneous speech'. It is easy to standardize the recording of counting and it is not subject to the contents of the patient's thoughts, as spontaneous 'propositional' speech (Hughlings Jackson, 1878) is likely to be. Furthermore, counting speed is less likely to be inadvertently manipulated by the examiner's prompting questions. 
2. Phonation time vs pause time. The separate measurement of phonation time and pause time yielded the information that pause time is elongated while the patient is depressed compared to a non-depressed period, whereas phonation time remain, constant throughout the period of observation. This is important, since in Parkinsonism, where hypokinesia (or retardation) is one of the prevailing clinical features, both pause time and phonation time change. The pause time itself is probably elongated; this, however, is often obscured by an apparent increase in phonation time due to 'slurring' of the speech (Mawdsley and Gamsu, 1977).

3. The constancy of both speech measures in healthy volunteers. We have shown that both phonation times and pause times are constant in healthy volunteers over longer periods, and thus the shortening of pause time with clinical improvement in the depressed patients cannot be due to a 'practice effect'.

4. Sensitivity of the tests. The comparison with other tests for motor retardation showed that the measurement of pause time was the most sensitive test, and it could reveal a degree of retardation in clinically non-retarded patients.

In conclusion, we believe that the analysis of the structure of 'automatic speech' in depression can provide information about psychomotor retardation which has not been available so far.

\section{E. Szabadi}

C. M. BradshaW

Department of Psychiatry, University of Manchester, West Didsbury, M20 8LR

Royal Edinburgh Hospital, Edinburgh

\section{References}

JAckson, J. Hughrings (1878) On affections of speech from disease to the brain. Brain, I, 304-30.

Mawdsley, C. \& Gamsu, C. V. (1971) Periodicity of speech in Parkinsonism. Nature, 231, 315-16.

Ounsted, C. (1977) Speech in depressive states. British Foumal of Psychiatry, 130, 315-16.

Szabadi, E., Bradshaw, C. M. \& Besson, J. A. O. (1976) Elongation of pause-time in speech: a simple, objective measure of motor retardation in depression. British Fournal of Psychiatry, 129, 592-7.

\section{ANOTHER STYLE OF PSYCHOGERIATRIC SERVICE}

Dear Sir,

I read the letters referring to the paper on "Another Style of Psycho-Geriatric Service' (Joumal, February 1977, 130, pp 123-26) with interest. Many of the points made require an answer and further consideration. In attempting to keep the paper short, we did leave out information about the other services in Gloucestershire, which I understand are as follows. Gloucester District, with about 300,000 population, has two geriatricians, 317 in-patient beds and 42 day places. Cheltenham District, with a population of about 200,000 , has one geriatrician, approximately 200 in-patient beds and 10 geriatric day places. In Gloucestershire residential homes there are 1,180 places, and some of these take in day residents.

There is a significant shortage of geriatric beds in Gloucester District, and in both Districts there is a significant shortage of geriatric day places and psychogeriatric places.

I meet regularly with the Local Authority Social Services, Home Help Organizers and Matrons of Part III Homes, and the maximum effort is given to helping old people live in their own homes, not just for sentimental or social reasons but because moves to institutional care makes most dementing patients worse. I would like to confirm the valuable work done by the Home Help and District Nurse service in many cases. All the Part III Homes contain a significant number of frail and dementing elderly patients, and the staff of these homes, too, manage many of them remarkably well, sometimes, indeed, better than we have done in hospital. Liaison between psychiatric hospital staff and Part III Homes is encouraged and many patients from Part III Homes attend the Day Hospitals.

Why is it assumed that there is a high degree of selectivity because plans for discharge are made before admission? The alternative is to admit without having any plan for discharge, which is demoralizing for the patient and can lead to misunderstanding with relatives.

Unfortunately, I have been unable to meet my three geriatric colleagues regularly on ward rounds and other occasions and am well aware of differences of opinion between us. However, two of the geriatricians were not in post as consultants when I came to Gloucestershire, and at that time I found that all the psychogeriatric beds were 'blocked', there was a waiting list for admission, and patients were admitted from geriatric services and Part III accommodation by 'swapping'. Quite contrary to the opinions expressed by the geriatricians, I am sure that as long as I have been at Coney Hill Hospital I have been helping the geriatricians by admitting seriously physically ill patients, simply because of their bed shortage. I find it difficult to believe that they are admitting many elderly patients with dementia but without significant physical disease (see H.M.(72) 71, paragraph 25). 